\title{
Identification of Novel Rodent-Borne Orthohantaviruses in an Endemic Area of Chronic Kidney Disease of Unknown Etiology $(\mathrm{CKDu})$ in Sri Lanka
}

\author{
Devinda S. Muthusinghe ${ }^{1} \mathbb{D}$, Kenta Shimizu ${ }^{2} \mathbb{D}$, Sithumini M. W. Lokupathirage ${ }^{1}$, Zhouoxing Wei ${ }^{1}$, \\ Yomani D. Sarathkumara ${ }^{3,4}$ (D) G. R. Amanda Fonseka ${ }^{3}\left(\mathbb{D}\right.$, Pavani Senarathne ${ }^{3}$, Nobuo Koizumi ${ }^{5}$, \\ Tomonori Kawakami ${ }^{6}$, Akio Koizumi ${ }^{7}$, Chaminda Wickramasinghe ${ }^{8}$, Hideki Ebihara ${ }^{9,+}$, Keita Matsuno ${ }^{10} \mathbb{D}_{\text {, }}$ \\ Yoshimi Tsuda $^{2, \ddagger}$, Jiro Arikawa ${ }^{2,}$, Chandika D. Gamage ${ }^{3, * \mathbb{D}}$ and Kumiko Yoshimatsu 1,11,*(D)
}

check for updates

Citation: Muthusinghe, D.S.;

Shimizu, K.; Lokupathirage, S.M.W.; Wei, Z.; Sarathkumara, Y.D.; Fonseka, G.R.A.; Senarathne, P.; Koizumi, N.; Kawakami, T.; Koizumi, A.; et al. Identification of Novel Rodent-Borne

Orthohantaviruses in an Endemic Area of Chronic Kidney Disease of Unknown Etiology (CKDu) in Sri Lanka. Viruses 2021, 13, 1984. https://doi.org/10.3390/v13101984

Academic Editor: Norbert Nowotny

Received: 2 September 2021

Accepted: 28 September 2021

Published: 2 October 2021

Publisher's Note: MDPI stays neutral with regard to jurisdictional claims in published maps and institutional affiliations.

Copyright: (c) 2021 by the authors. Licensee MDPI, Basel, Switzerland. This article is an open access article distributed under the terms and conditions of the Creative Commons Attribution (CC BY) license (https:/ / creativecommons.org/licenses/by/ $4.0 /)$.
1 Graduate School of Infectious Diseases, Hokkaido University, Sapporo 060-0818, Japan; devindasm@med.hokudai.ac.jp (D.S.M.); sithuminilokupathirage@czc.hokudai.ac.jp (S.M.W.L.); lamtuanglavaron@gmail.com (Z.W.)

2 Department of Microbiology and Immunology, Faculty of Medicine, Hokkaido University, Sapporo 060-8638, Japan; kshimizu@med.hokudai.ac.jp (K.S.); tsuday@nagasaki-u.ac.jp (Y.T.); arikawaj@nagasaki-u.ac.jp (J.A.)

3 Department of Microbiology, Faculty of Medicine, University of Peradeniya, Peradeniya 20400, Sri Lanka; yomani.sarathkumara@my.jcu.edu.au (Y.D.S.); gramandafonseka@gmail.com (G.R.A.F.); pavanisenarathne@gmail.com (P.S.)

4 Australian Institute of Tropical Health and Medicine, James Cook University, Cairns, QLD 4878, Australia

5 Department of Bacteriology I, National Institute of Infectious Diseases, Tokyo 162-8640, Japan; nkoizumi@niid.go.jp

6 Department of Environmental and Civil Engineering, Faculty of Engineering, Toyama Prefectural University, Toyama 939-0398, Japan; kawakami@pu-toyama.ac.jp

7 Department of Health and Environmental Sciences, Kyoto University Graduate School of Medicine, Kyoto 606-8501, Japan; koizumi@kyoto-hokenkai.or.jp

8 Postgraduate Institute of Science, University of Peradeniya, Peradeniya 20400, Sri Lanka; wmcwick@gmail.com

9 Department of Molecular Medicine, Mayo Clinic, Rochester, MN 55905, USA; hebihara@niid.go.jp

10 International Institute for Zoonosis Control, Hokkaido University, Sapporo 001-0020, Japan; matsuk@czc.hokudai.ac.jp

11 Institute for Genetic Medicine, Hokkaido University, Kita-ku, Kita-15, Nishi-7, Sapporo 060-0815, Japan

* Correspondence: chandika.gamage@med.pdn.ac.lk (C.D.G.); yosimatu@igm.hokudai.ac.jp (K.Y.); Tel.: +81-11-706-7547 (K.Y.)

+ Present Address: Department of Virology I, National Institute of Infectious Diseases, Tokyo 162-8640, Japan.

$\ddagger$ Present Address: Nagasaki University, Nagasaki 852-8521, Japan.

Abstract: We reported the genetic evidence of circulating hantaviruses from small mammals captured in a chronic kidney disease of unknown etiology (CKDu) hotspot area of Sri Lanka. The high seroprevalence of anti-hantavirus antibodies against Thailand orthohantavirus (THAIV) has been reported among CKDu patients and rodents in Sri Lankan CKDu hotspots. We captured 116 small mammals from CKDu endemic regions in the Polonnaruwa District of Sri Lanka. Seven animals (five out of 11 Mus booduga and two out of 99 Rattus rattus) were PCR-positive for the hantavirus. A rat-borne sequence was grouped with a THAIV-like Anjozorobe virus. In contrast, Mus-borne sequences belonged to the THAIV lineage, suggesting a novel orthohantavirus species according to the phylogenetic analyses and whole-genome comparisons. Our genetic evidence indicates the presence of two THAIV-related viruses circulating in this CKDu endemic area, suggesting a basis for further investigations to identify the infectious virus in patients with CKDu and the CKDu induction mechanism of these viruses.

Keywords: hantavirus; Mus booduga; Thailand orthohantavirus; Anjozorobe hantavirus 


\section{Introduction}

A previously unexplained form of renal disease, referred to as a chronic kidney disease of unknown etiology (CKDu), has been increasingly diagnosed over the past three decades in dry zone areas of Sri Lanka, becoming an overwhelming public health burden [1]. This disease has become more prevalent among rural agricultural communities [2], where males are more often affected than females [3]. Affected individuals show no symptoms until the disease progresses into its late stages. Areas in 13 out of 25 districts in the country have been identified as high-risk regions for the occurrence of CKDu. North Central Province alone has reported approximately 20,000 CKDu patients with a population prevalence rate of $4.7 \%$ [4]. The scarcity of recent incidence data has made it difficult to understand the current prevalence of CKDu in the country. Moreover, despite many studies conducted over the past few decades, the etiology of CKDu remains obscure.

Hantaviruses are a group of zoonotic pathogens belonging to the family Hantaviridae of the order Bunyavirales. The spherical enveloped viral particles consist of a tri-segmented negative-strand RNA genome. The large (L), medium (M), and small (S) genome segments encode an L-protein, a glycoprotein precursor (GPC) of two envelope glycoproteins $\mathrm{Gn}$ and $\mathrm{Gc}$, and a nucleocapsid protein $(\mathrm{N})$, respectively [5]. Hantaviruses currently have a relatively diverse host range, with rodents, shrews, moles, and bats being the common hosts. Interestingly, all medically important human pathogenic hantaviruses are carried by rodent hosts [6]. Hemorrhagic fever with renal syndrome (HFRS) in Eurasia and hantavirus cardiopulmonary syndrome (HCPS) represents two severe forms of human infections caused by hantaviruses. HCPS shows a higher fatality rate (25-35\%) than HFRS in Asia (5-15\%) [7]. East Asia accounts for approximately $90 \%$ of HFRS cases caused by Old World orthohantaviruses, such as the Hantaan virus (HTNV) and Seoul virus (SEOV) [8]. Southeast Asia, South Asia, and the Indian oceanic region are home to the Thailand orthohantavirus (THAIV) [9] and its genetic variants (the Anjozorobe (ANJZV) [10], Serang [11], Jurong [12], and Mayotte [13] viruses). The pathogenicity of these viruses remains unexplained because of the lack of data. Although several sero-epidemiological reports have described human infections involving THAIV in Thailand, India, and Sri Lanka [14-16] and ANJZV in Madagascar [17], there are no confirmed clinical cases of HFRS or HCPS documented in South Asia or Southeast Asia. Epidemiological information on hantaviruses and their hosts is limited, particularly in South Asian countries [8].

Hantavirus infection was first documented in Sri Lanka as early as 1988 by Vitarana and colleagues [18]. Since then, very few reports have been published on individuals with suspected leptospirosis who have been found to possess anti-hantavirus antibodies $[19,20]$. It was recently reported by Gamage et al. that 72 (54.5\%) out of $132 \mathrm{CKDu}$ patients from the CKDu endemic area of Girandurukotte, Sri Lanka harbored antibodies against hantaviruses [21]. The existence of THAIV- or THAIV-related hantavirus infections was confirmed by serotyping 89 anti-hantavirus antibody-positive human serum samples obtained from the same area [22]. Similarly, high levels of antibodies against the hantavirus were reported among CKDu patients from a CKDu hotspot in Polonnaruwa District in the North Central Province of Sri Lanka [23]. In addition, a cross-sectional study carried out with case-control comparisons in two geographically distinct CKDu endemic areas vs. a nonendemic area in Sri Lanka demonstrated that exposure to the hantavirus was an independent risk factor associated with renal disease in the CKDu endemic regions [24]. An ecoepidemiological study in Girandurukotte serologically confirmed that THAIV-like hantavirus species were highly prevalent among the Rattus rattus lineage [25]. Serological findings from both humans and rodents in the CKDu areas supported the hypothesis that exposure to hantaviruses is a risk factor for the possible development of CKDu in Sri Lanka [26]. However, no studies have provided the genomic evidence from hantavirus rodent hosts circulating in Sri Lanka. Viral genomic information is essential in developing specific diagnostics to detect hantavirus infections in CKDu patients. The results will add further insights into the relationship between exposure to a hantavirus and CKDu etiology. Therefore, the current study aimed to address this knowledge gap. Hence, this report 
describes a genetic analysis of small mammals captured from a CKDu endemic area in Sri Lanka to determine the hantavirus species and possible natural hosts.

\section{Materials and Methods}

\subsection{Sample Collection}

Small mammal samples were collected in September 2018 and July 2019 from the Polonnaruwa, Welikanda, and Sinhapura areas in Polonnaruwa District, where CKDu is highly prevalent (Figure 1). The study protocol was approved by the Ethics Committee of the Faculty of Veterinary Medicine and Animal Sciences of the University of Peradeniya, Sri Lanka (VER-16-007). In September 2018, rodent trapping was performed using cagetype traps to capture the first 98 rodents. Most of the traps used in July 2019 were Sherman traps (H. B. Sherman Traps, Inc., Tallahassee, FL, USA), and 18 additional rodents and shrews were collected. The captured species were initially identified based on their morphology. The animals' body weight, sex, and other body parameters were recorded. The lungs, liver, kidneys, and blood samples from a heart puncture were collected from each animal. Parts of the lung and kidney tissues were preserved in RNAlater (Qiagen, Hilden, Germany), and a portion of the kidneys were preserved in 99.5\% ethanol (Sigma-Aldrich, Burlington, MA, USA).

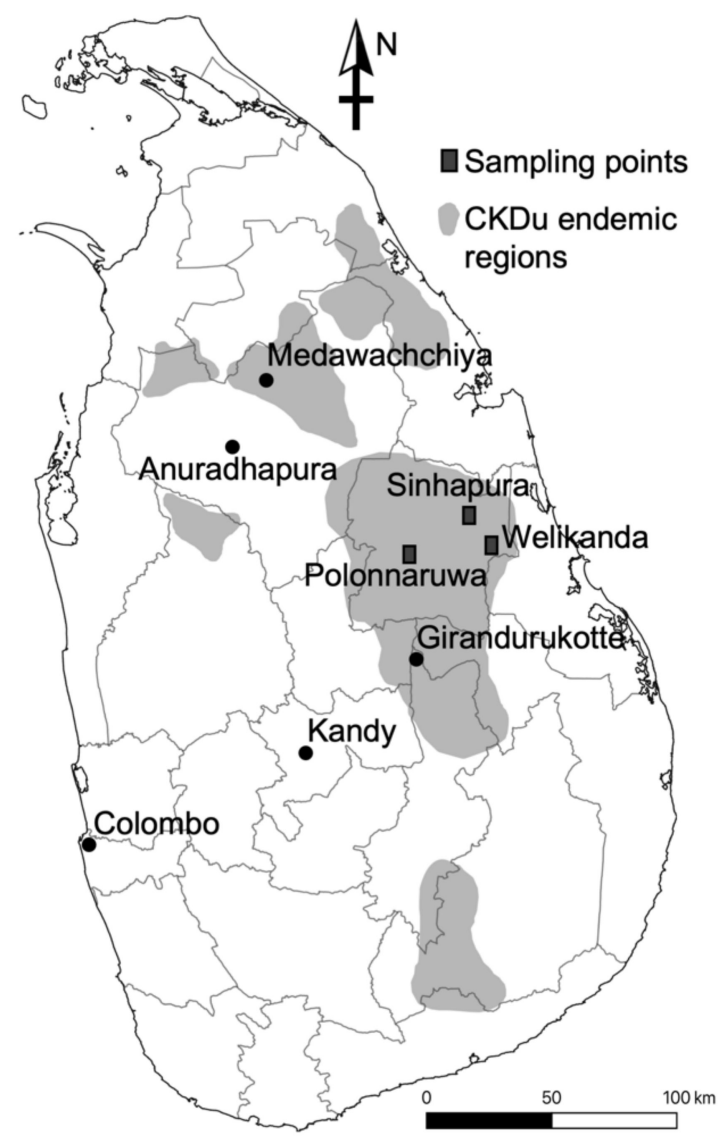

Figure 1. Map of Sri Lanka showing the CKDu endemic regions and sampling points of the study.

\subsection{DNA Extraction and Rodent Species Identification}

The DNA was extracted from small mammal kidney tissues preserved in ethanol using the DNAzol reagent (Invitrogen, Thermo Fisher Scientific, Carlsbad, CA, USA) according to the manufacturer's instructions. PCR was performed on kidney DNA samples to amplify a mitochondrial cytochrome b (cytb) gene using AmpliTaq Gold ${ }^{\circledR} 360$ DNA polymerase (Applied Biosystems, Life Technologies, Warrington, UK) and the primers L14115, H15300, L497A, and H655A [27,28]. The PCR program consisted of 10 min of initial denaturation at 
$95^{\circ} \mathrm{C}$; 35 cycles of $95^{\circ} \mathrm{C}$ for $30 \mathrm{~s}, 55^{\circ} \mathrm{C}$ for $30 \mathrm{~s}$, and $72{ }^{\circ} \mathrm{C}$ for $30 \mathrm{~s}$; and a final extension at $72^{\circ} \mathrm{C}$ for $7 \mathrm{~min}$. The nucleotide sequences of the amplified $c y t b$ fragments were determined using a BigDye Terminator v3.1 cycle sequencing kit (Applied Biosystems) and a 3130xl Genetic Analyzer (Applied Biosystems).

\subsection{Indirect Immunofluorescence Assay (IFA)}

Anti-hantavirus IgG antibodies were detected in small mammal sera using IFAs based on antigens from THAIV-infected and recombinant THAIV N protein-expressing Vero E6 cells, as described elsewhere [29]. Alexa Fluor 488-conjugated goat anti-rat IgG (for rat and Bandicota sera), anti-mouse IgG (for mouse sera) (Invitrogen), and protein A (for shrew and gerbil sera) were used as the secondary antibodies. Each serum sample was diluted 1:100 in PBS. Scattered granular immunofluorescence patterns in the cell cytoplasm were considered to indicate positive staining.

\subsection{RNA Extraction, cDNA Synthesis, and Hantavirus Screening PCR}

RNA extraction was performed from lung and kidney tissues of all the small mammals preserved in RNAlater using the RNeasy Plus mini kit (Qiagen) following the manufacturer's instructions. cDNA synthesis from the total RNA was carried out using the SuperScript IV VILO Master mix (Invitrogen). All lung cDNA samples were screened by PCR using AmpliTaq Gold ${ }^{\circledR} 360$ DNA polymerase and degenerate primers [30] targeting a conserved domain of the $\mathrm{L}$ genome segment of hantaviruses. The HAN-L-F2 (5'TGCWGATGCHACIAARTGGTC-3') and HAN-L-R1 (5'-AACCADTCWGTYCCRTCATC$\left.3^{\prime}\right)$ primers were used for the first round, followed by hemi-nested amplification using the HAN-L-F2 and HAN-L-R2 (5'-GCRTCRTCWGARTGRTGDGCAA- $\left.3^{\prime}\right)$ primers. Both amplification reactions included $10 \mathrm{~min}$ of initial denaturation at $95^{\circ} \mathrm{C} ; 35$ cycles of $95^{\circ} \mathrm{C}$ for $30 \mathrm{~s}, 55^{\circ} \mathrm{C}$ for $30 \mathrm{~s}$, and $72{ }^{\circ} \mathrm{C}$ for $30 \mathrm{~s}$; and a final extension at $72^{\circ} \mathrm{C}$ for $7 \mathrm{~min}$. Amplified PCR products with correct sizes were purified and sequenced as described previously.

\subsection{Genomic Sequencing}

All the screening PCR-positive samples were selected for hantavirus whole-genome sequencing via either the primer walking method or Illumina MiSeq sequencing. In the primer walking method, the primers were designed for all three genomic segments based on the initial sequences obtained in this study and previously published Muridae-borne hantavirus sequences (Supplemental Tables S1-S3) and were used to amplify segments of the genome, not including the termini. The PCR products were gel-purified and sequenced by Sanger sequencing, as described above.

For the Illumina MiSeq analysis, the RNA fractions extracted from lung tissues, as described above, were treated with the Ribo-Zero rRNA removal kit (Illumina, San Diego, CA, USA) to deplete host-derived rRNA. The treated RNAs were employed to construct sequencing libraries using the KAPA RNA HyperPrep kit (for Illumina) and the KAPA Dual-Indexed adapter kit (KAPA Biosystems, Wilmington, MA, USA). Twenty-four libraries and other nonrelated samples were mixed in equal amounts to obtain $9 \mathrm{fmol}$ of a MiSeq library, which was then sequenced on the Illumina MiSeq platform using the MiSeq reagent kit v3 (Illumina) with $2 \times 300-b p$ paired-end read lengths.

Since there is no reported complete sequence of the prototype THAIV L segment available for the whole-genome comparison, the entire L segment sequence of THAIV strain-749 (LC553715) was determined using the cDNA of the virus. The primer walking method was carried out using degenerate primers designed as described above (Supplemental Table S3), and the amplicons were sequenced by Sanger sequencing, as described previously. To complete the terminal sequences, the RACE method was applied as previously described [31] using the adapter sequences [31] and specific primers shown in Supplemental Table S3. 


\subsection{Sequence Alignment and Phylogenetic Analysis}

The sequences obtained via Sanger sequencing were manually edited and aligned with reference genome sequences obtained from DNA databases. At the same time, the MiSeq reads were mapped onto reference genomes using GENETYX-MAC version 20.1.0 (Genetics Co., Ltd., Tokyo, Japan). The full-length sequences obtained from the S, M, and $\mathrm{L}$ segment ORFs aligned with representative sequences from other Muridae-borne hantaviruses using MUSCLE, as implemented in Geneious Prime ${ }^{\circledR}$ 2020.2.2 (Biomatters, Ltd., Auckland, New Zealand). Multiple sequence alignments were edited and used to construct Bayesian phylogenetic trees using the MrBayes 3.2.6 [32] plug-in of Geneious Prime ${ }^{\circledR}$ 2020.2.2 with the GTR + G + I substitutional model. Consensus cladograms were constructed using viral $\mathrm{N}$ protein amino acid sequences, and host $c y t b$ sequences were compared for the degree of concordance using Dendroscope V3.7.2. [33] to describe the coevolutionary relationships between the hantaviruses and hosts identified in this study, along with other representative rodent-, mole-, shrew-, and bat-borne hantaviruses and their hosts.

\subsection{Quantification of Viral RNA}

Whole-genome-positive rodent lung and kidney cDNAs were subjected to a quantitative real-time PCR analysis. For the Mus cDNA samples, primers LANS_F (5'-GAGAGCAT GCCAGGGGTGCAGG-3') and LANS_R (5'-GTAGGTGGACACCTATCAGGAGC-3') were used. For the $R$. rattus cDNA samples, primers SA108S_F (5'-GATCATGCTAGGGATGCTG G-3') and SA108S_R (5'-GTAGGAGGACACCGATCAGGTGC-3') were used, with the KAPA SYBR FAST qPCR master mix (KAPA Biosystems) and a Light Cycler 480 instrument II (Roche, Indianapolis, IN, USA) according to the manufacturer's instructions.

\section{Results}

\subsection{Animal Species Identification}

Morphological identification showed that the most (99/116) of the captured small mammals were Rattus rattus. An analysis of the cytb sequences from several animals confirmed that they belonged to lineage $\mathrm{Ib}$, a Sri Lankan endemic lineage of $R$. rattus $[25,28]$. Eleven animals were identified as Mus booduga (Little Indian field mouse) after analyzing the $c y t b$ sequences (Supplemental Figure S1). We identified two clusters of M. booduga sequences in the phylogeny, which differed from the M. booduga sequences from India and Nepal. The other rodent and shrew species captured in this study were Tatera indica (Indian Gerbil) $(n=3)$, Bandicota bengalensis $(n=1)$, Bandicota indica $(n=1)$, and Crocidura horsfieldii $(n=1)$ (Table 1).

Table 1. Summary of the captured species and test results.

\begin{tabular}{cccc}
\hline Species & $\begin{array}{c}\text { No. of Captured } \\
\text { Animals }\end{array}$ & $\begin{array}{c}\text { IFA Antibody } \\
\text { (\% Positive) }\end{array}$ & $\begin{array}{c}\text { PCR } \\
\text { (\% Positive) }\end{array}$ \\
\hline Rattus rattus complex & 99 & $34(34.3 \%)$ & $2(2 \%)$ \\
Mus booduga & 11 & $5(45.5 \%)$ & $5(45.5 \%)$ \\
Tatera indica & 3 & 0 & 0 \\
Bandicota bengalensis & 1 & 1 & 0 \\
Bandicota indica & 1 & 0 & 0 \\
Crocidura horsfieldii & 1 & 0 & 0 \\
Total & 116 & 40 & 7 \\
\hline
\end{tabular}

\subsection{Sero-Survey and Hantavirus Screening PCR}

As shown in Table 1, a total of $36.4 \%(40 / 116)$ of the captured animals were seropositive for anti-hantaviral antibodies in an IFA. Thirty-four out of $99 R$. rattus individuals were seropositive, as were $5 / 11 \mathrm{M}$. booduga and $1 / 1 \mathrm{~B}$. bangelensis. Genome screening was performed for all the small mammal lung cDNA samples. Out of 116 captured animals, seven were positive by the hantavirus genome screening PCR (Table 1). Positive amplicons 
were obtained from $M$. booduga (5/11) and R. rattus (2/99). All five seropositive M. booduga were PCR-positive, resulting in a high positive rate of $45.5 \%(5 / 11)$. Conversely, among 34 seropositive $R$. rattus, only one was PCR-positive. PCR positivity was also detected in a seronegative $R$. rattus individual. Whole-genome sequencing was carried out to determine the respective hantavirus species precisely.

\subsection{Whole-Genome Sequencing}

We determined nearly complete whole-genome sequences of six of the seven PCR screening-positive samples using the primer walking and MiSeq approaches. The accession numbers of the genome segment sequences determined in this study are listed in Supplemental Table S4. All Mus-borne hantavirus sequences were similar in the sequence identities and showed less similarity to those of all known THAIV-like viruses. Therefore, these Mus-borne sequences were designated as the Lanka virus. The sequences determined from M. booduga sample \#98 (PR98) were used to represent Lanka viruses for further analyses, as it was the first Mus sample to obtain the whole genome of the Lanka virus. We failed to determine the whole-genome sequence from the seronegative rat (\#32) that was positive according to PCR screening, and its amplicon sequence was identical to that of the Lanka virus. Sequence comparisons with other representative Muridae-born hantaviruses revealed that PR98 was the closest to ANJZV, and its S, M, and L segment open reading frames (ORFs) showed 62.6-80.1\%, 59.4-76.9\%, and 74-79.7\% nucleotide identities, respectively, while the encoded N, GPC, and L proteins showed 61.4-93.2\%, 53.6-87.2\%, and 68.5-94.5\% amino acid identities, respectively (Table 2). Another seropositive rat (\#108) carried sequences differing from those of the Lanka virus. The sequence analysis of this $R$. rattus-borne virus, designated as strain SA108 (SA108; Sri Lankan ANJZV detected from rat \#108) showed high similarity to ANJZV, a genetic variant of THAIV in the $R$. rattus species from the Madagascar Islands. SA108 led to a similar sequence identity range (Supplemental Tables S5-S7). The predicted GPC cleavage site, having a conserved WAASA motif, could be observed at amino acid positions $642-646$ in both strains. The novel Lanka virus detected from $M$. booduga showed a high divergence from all the known THAIV-like viruses at both nucleotide and amino acid levels. The $\mathrm{M}$ segment nucleotide and amino acid sequences of the Lanka virus showed the lowest identity with the THAIV and THAIV-like viruses (Table 2 and Supplemental Table S6). In contrast, those of the L segment showed the highest identity values (Table 2 and Supplemental Table S7).

Table 2. Nucleotide and amino acid sequence identities of $S, M$, and L segment ORFs and their corresponding encoded proteins of the Lanka virus strains PR98 with SA108 and other representative Muridae-born hantaviruses.

Lanka Virus Strain-PR 98

\begin{tabular}{|c|c|c|c|c|c|c|}
\hline & \multicolumn{3}{|c|}{ Nucleotide Identity, \% } & \multicolumn{3}{|c|}{ Amino Acid Identity, \% } \\
\hline & ORF_S & ORF_M & ORF_L & $\mathbf{N}$ & GPC & L-protein \\
\hline THAIV & 78.1 & 76.6 & 79.2 & 92.1 & 85.4 & 94.0 \\
\hline ANJZV & 79.4 & 76.9 & 79.5 & 93.2 & 86.7 & 94.3 \\
\hline SA108 & 80.1 & 76.9 & 79.7 & 93.0 & 87.2 & 94.5 \\
\hline SEOV & 75.0 & 72.3 & 76.7 & 85.8 & 79.7 & 88.3 \\
\hline HTNV & 74.0 & 71.2 & 74.0 & 84.1 & 76.8 & 84.8 \\
\hline DOBV & 72.6 & 70.7 & 74.2 & 83.2 & 75.7 & 85.6 \\
\hline PUUV & 62.6 & 59.4 & 66.9 & 61.4 & 53.6 & 68.5 \\
\hline $\begin{array}{l}\text { THAIV stra } \\
\text { zorobe/Em/ } \\
\text { strain 80-39 } \\
\text { M14627, and } \\
\text { and Puumala }\end{array}$ & $\begin{array}{l}\text { 901); Dobr } \\
\text { (PUUV) s }\end{array}$ & Sotkamo & in Dobra & $\begin{array}{ll}\mathrm{L}: & \mathrm{L} \\
\text { and } & \mathrm{L}\end{array}$ & $\begin{array}{l}; \quad \text { AN } \\
922) ; \quad 5 \\
\text { HTN7 } \\
\text { M: L336 }\end{array}$ & $\begin{array}{l}\text { strain Anj } \\
\text { virus (SEO) } \\
\text { (S: M14626, N } \\
\text { d L: JQ02620 }\end{array}$ \\
\hline
\end{tabular}




\subsection{Sequence Alignment and Phylogenetic Analysis}

A phylogenetic analysis based on the ORFs of all three genomic segments of the SA108 and Lanka viruses clustered them with THAIV-like viruses (Figure 2 and Supplemental Figures S2 and S3). The Lanka virus showed a quite divergent topology in the phylogenetic trees, following the sequence identity results. The Lanka virus formed the basal clade in the $\mathrm{S}$ and $\mathrm{M}$ trees, where THAIV and its genetic variants seemed to diverge from the virus later. The tanglegram (Figure 3) illustrating the host-virus evolutionary relationships clearly showed the grouping of $M$. booduga, the Lanka virus host, with Apodemus and Hylomyscus species, which are the hosts of the Hantaan, Dobrava, and Sangassou orthohantaviruses found in Eurasia and Africa (Figure 3). The results revealed a notable difference since all the other THAIV-like hantavirus reservoir hosts were clustered into the Bandicota and Rattus groups (i.e., THAIV (Bandicota indica), ANJZV and Mayotte virus (R. rattus), Serang virus, and Jurong virus (R. tanezumi)).

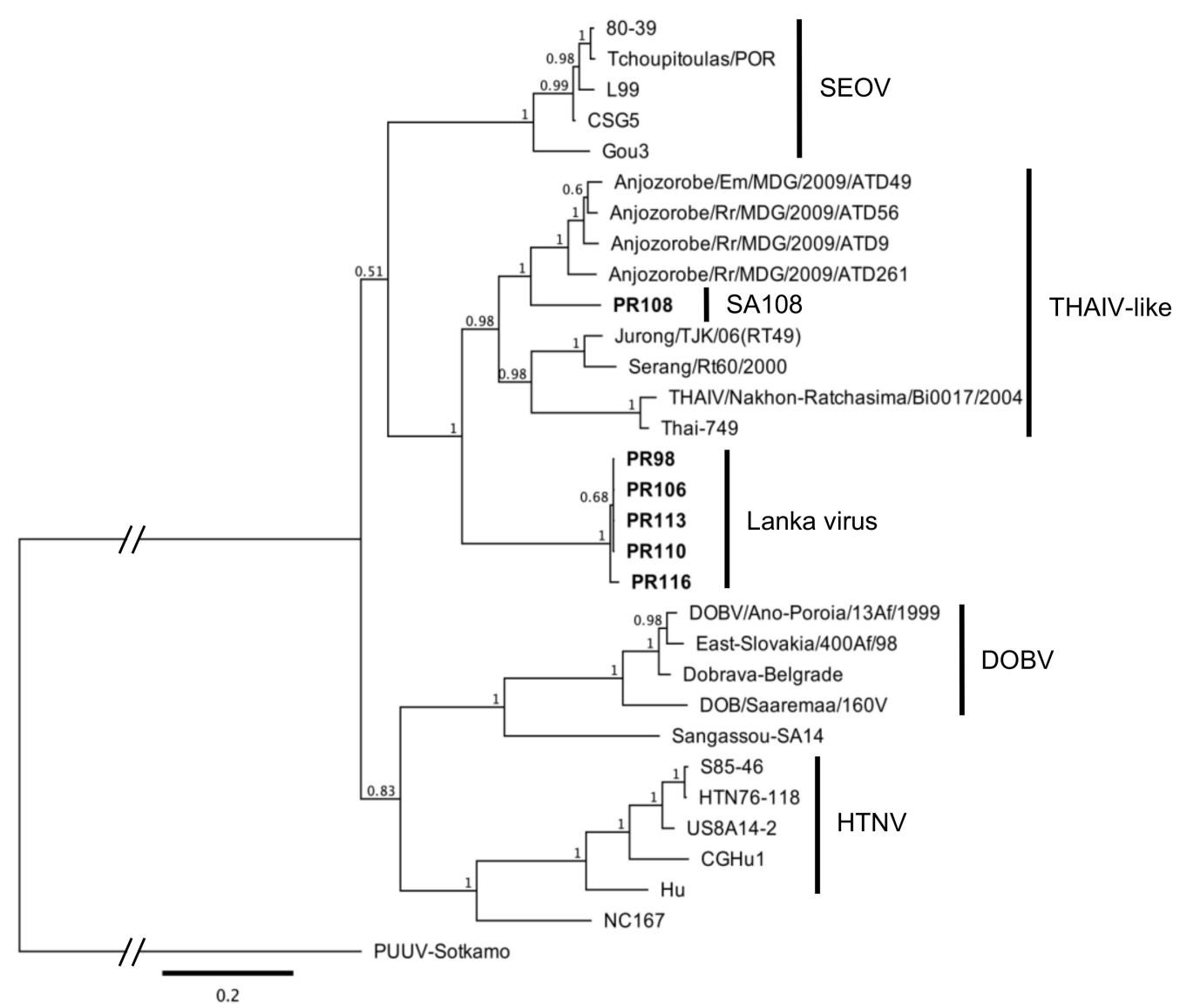

Figure 2. Phylogenetic tree based on S-segment ORF sequences representing the Muridae-borne hantaviruses and newfound viruses (shown in boldface) from this study. The scale bar indicates a sequence divergence of 0.2. The numbers above the nodes indicate the Bayesian posterior probability values. Hantaan (HTNV): S85-46 (AF288659), HTN76-118 (M14626), US8A14-2 (KU207208), CGHu1 (EU092218), and Hu (AB027111); Dabieshan: NC167 (AB027523); Seoul (SEOV): Gou3 (AF184988), L99 (AF288299), CSG5 (AB618112), Tchoupitoulas-POR (KU204960), and 80-39 (AY273791); Dobrava (DOBV): DOBV/Ano-Poroia/Afl9/1999 (AJ410615), Dobrava-Belgrade (L41916), East Slovakia/400Af/98 (AY168576), and DOB/Saaremaa/160V (AJ009773); Sangassou: SA14 (JQ082303); THAIV: Nakhon Ratchasima/Bi0017/2004 (AM397664), Thai-749 (AB186420), ANJZV strain Anjozorobe/Em/MDG/2009/ATD49 (KC490918), ANJZV strain Anjozorobe/Rr/MDG/2009/ATD56 (KC490916), ANJZV strain Anjozorobe/Rr/MDG/2009/ATD9 (KC490915), ANJZV strain Anjozorobe/Rr/MDG/2009/ATD261 (KC490914), Jurong strain TJK/06/RT49 (GQ274940), and Serang strain Serang/Rt60/2000 (AM998808); and Puumala (PUUV): Sotkamo (X61035). 


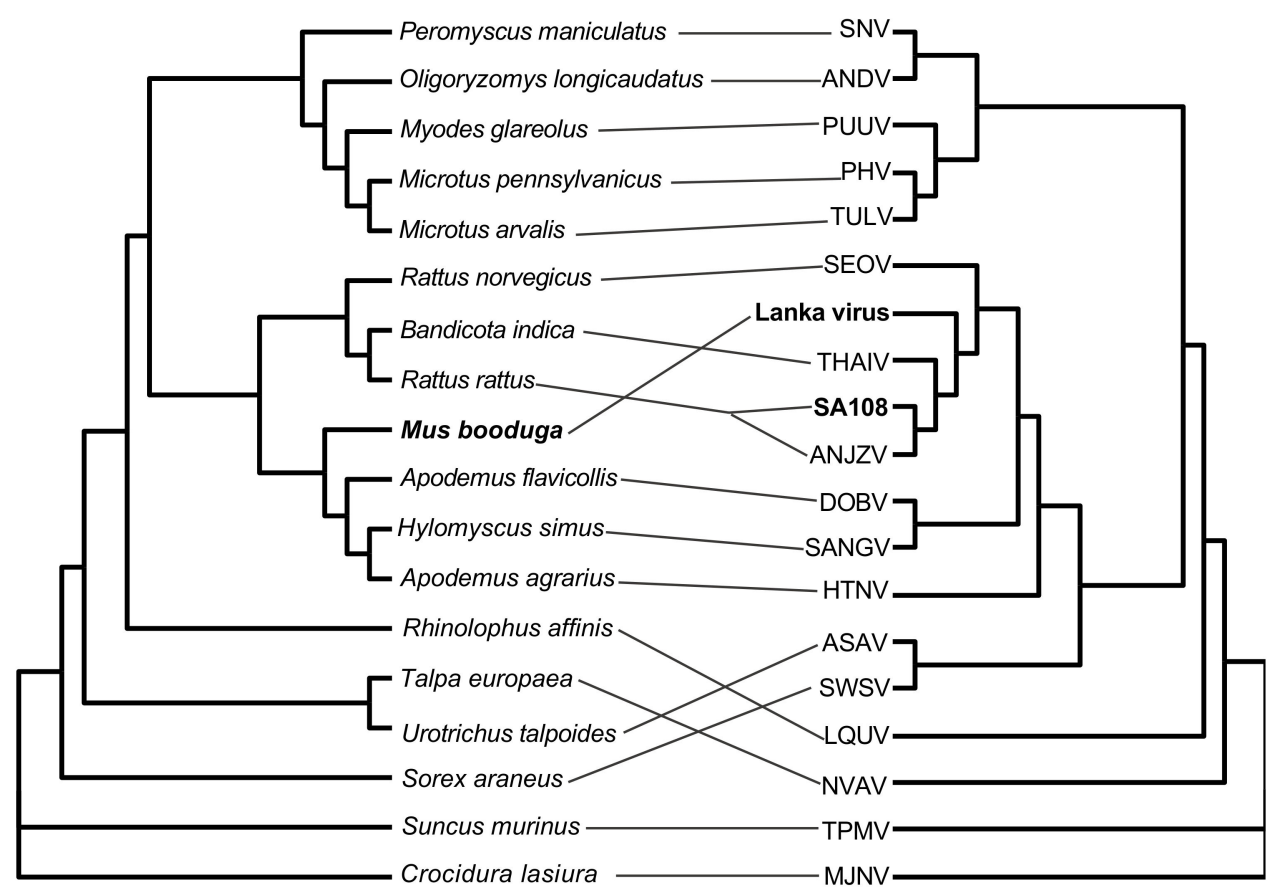

Figure 3. Tanglegram comparing the phylogenies of the representative hantaviruses and their hosts. The phylogeny of viruses based on amino acid sequences of the $\mathrm{N}$ protein (on the right) is compared with the $c y t b$ sequence-based phylogeny of their hosts (on the left). The newfound viruses are designated as the Lanka virus (LC553716) and SA108 (LC553722) in boldface, and the Lanka virus host Mus booduga (LC556235) is also shown in boldface. The other viruses used in the analysis include the shrew-borne thottimviruses Imjin virus (MJNV, KJ420559) from Crocidura lasiura (KJ004674) and Thottopalayam virus (TPMV, AY526097) from Suncus murinus (JF784171); the mole-borne Nova mobatvirus (NVAV, KR072621) from Talpa europaea (KF801566); the bat-borne Longquan loanvirus (LQUV, JX465422) from Rhinolophus affinis (DQ297582); the shrew-borne Seewis orthohantavirus (SWAV, KY651020) from Sorex araneus (AJ245893); the mole-borne Asama orthohantavirus (ASAV, EU929072) from Urotrichus talpoides (AB033611); the rodent-borne orthohantaviruses Seoul virus (SEOV, AY273791) from Rattus norvegicus (AB033713), the Thailand virus (THAIV, AM397664) from Bandicota indica (KJ592790), the Dobrava-Belgrade virus (DOBV, AJ410615) from Apodemus flavicollis (AY158445), the Sangassou virus (SANGV, JQ082300) from Hylomyscus simus (JX893846), the Hantaan virus (HTNV, M14626) from Apodemus agrarius (AB032851), the Sin Nombre virus (SNV, L25784) from Peromyscus maniculatus (JF489123), the Andes virus (ANDV, AF291702) from Oligoryzomys longicaudatus (KR822254), the Tula virus (TULV, Z49915) from Microtus arvalis (GU187363), the Prospect Hill virus (PHV, Z49098) from Microtus pennsylvanicus (KF948531), the Puumala virus (PUUV, X61035) from Myodes glareolus (FJ881480); and the THAIV genetic variant Anjozorobe virus (ANJZV, KC490918) from Rattus rattus (AB033702).

\subsection{Quantification of Viral RNA}

Higher viral RNA copy numbers were detected in lung tissues than in kidney tissues in all the rodent samples. $R$. rattus (PR108) had a notable difference in the viral RNA copy numbers between the two tissue types. All the $M$. booduga kidney tissues showed viral copy number values higher than $10^{5}$ copies $/ \mathrm{mg}$, while the single SA108-infected $R$. rattus kidney tissue sample showed a lower value (Figure 4). 


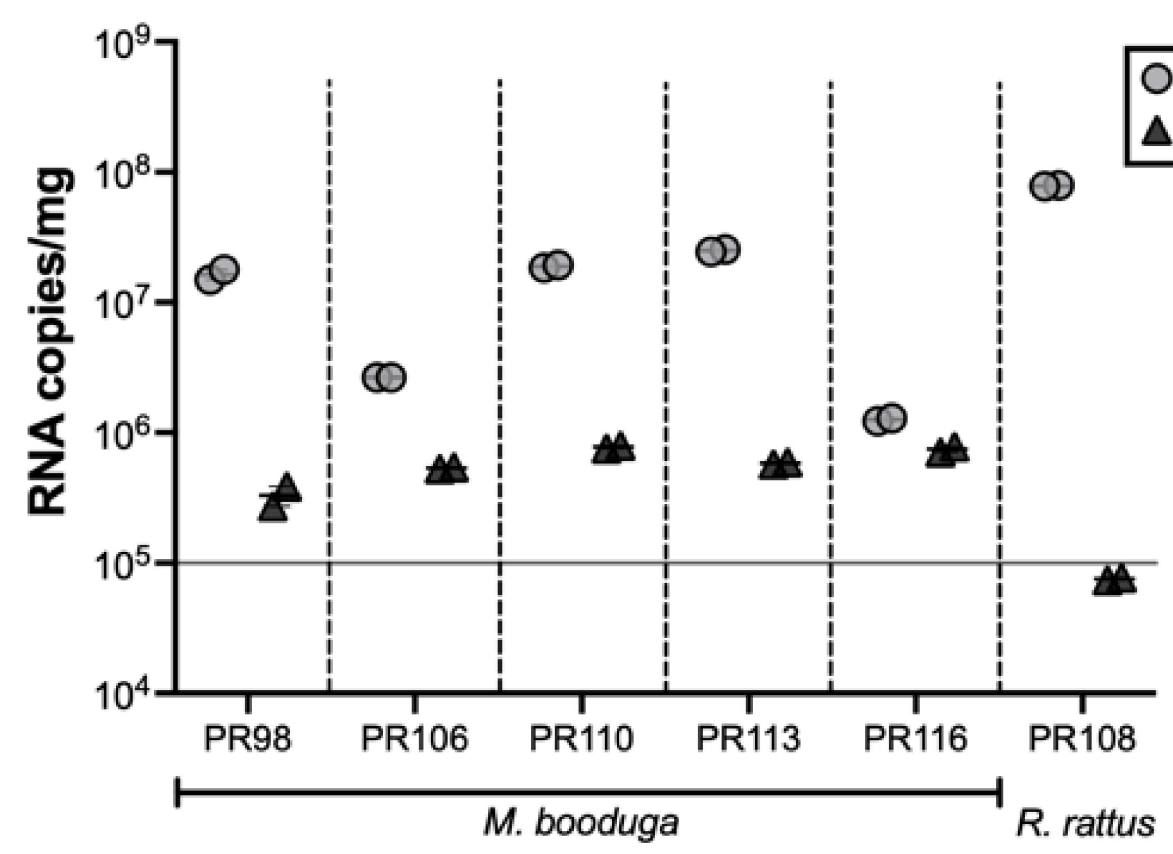

Figure 4. Viral RNA copy numbers in lung and kidney tissues of hantavirus genome-positive rodents. Tissues from $M$. booduga and $R$. rattus were examined by quantitative real-time PCR using the Lanka virus primer set and the SA108 primer set, respectively. The two markers of each sample show the two replicated runs of the same cDNA sample, and the error bars representing the standard error and the median of the duplicates are shown for each sample.

\section{Discussion}

In this study, we report the detection of two novel hantaviruses, the Lanka virus and an ANJZV variant from Sri Lanka. The Lanka virus detected from M. booduga shows notable differences from all known THAIV genetic variants and from the THAIV prototype. The differences identified in the Lanka virus $\mathrm{S}$ and $\mathrm{M}$ segments and their corresponding proteins suggest the unique adaptation of this virus to its host, $M$. booduga. The S and M genomic sequences of the Lanka virus are placed as the basal branches of the THAIV-like clades in the corresponding phylogenetic trees, indicating that the Lanka virus might be the most ancient lineage of the THAIV-like hantaviruses. Based on the most recent proposed taxonomy guidelines, hantaviruses showing pairwise evolutionary distance (PED) values for the N protein and GPC concatenated amino acid sequences greater than 0.1 are considered distinct orthohantavirus species [34]. The corresponding values for the Lanka virus are $0.1344,0.1214$, and 0.1159 compared with the THAIV, ANJZV, and Jurong virus, respectively, suggesting that the Lanka virus is a novel, distinct orthohantavirus species. The tanglegram analysis further supported this hypothesis by accommodating the Lanka virus host in a different group of rodents from the usual THAIV-like virus hosts.

THAIV and its genetic variants, such as the ANJZV and Mayotte, Jurong, and Serang viruses, are carried primarily by Bandicota and Rattus species. Initially, rats were the targets of trapping, and we used only cage-type traps. As a result, many seropositive rats were captured, but a virus genome was not identified from any of them [25]. A partial Lanka virus genome was first detected from a seronegative rat (\#32) after heminested PCR. This rat was thought to be in the early phase of infection. Seropositive but genome-negative rats were considered to have recovered from a spillover infection rather than representing a reservoir of the Lanka virus or SA108. Additionally, the fact that the rats can easily experience a spillover infection directly explains why humans living in the same field exhibit the same chance of infection as rats. A single mouse, \#98, was captured in a cagetype trap, and this mouse seemed to be a hantavirus reservoir. After that, we switched to traps for capturing mice and ultimately succeeded in identifying the Lanka virus. All the genome-positive mice were captured within the Sinhapura area and had a relatively 
dispersed origin. M. booduga sample PR116 was collected from a location relatively far from the area where other genome-positive $M$. booduga samples were collected. The differences in the PR116-borne Lanka virus nucleotide sequences suggest the possible diversity among the Lanka viruses distributed in CKDu endemic areas and possibly in other regions as well.

To our knowledge, this is the first report providing genetic evidence of $M u$ s species acting as hantavirus reservoir hosts. Several studies describing hantavirus genome detection in Mus musculus appear to represent spillover infections from reservoir hosts found in the same environmental habitats [35-39]. A perusal of the available literature revealed that the M. booduga species is distributed in East Pakistan, India, Southern Nepal, Sri Lanka, Bangladesh and Myanmar [40]. The finding that Sri Lankan M. booduga sequences are distinct from those found in India and Nepal (Supplemental Figure S1) indicates that the Sri Lankan M. booduga evolved as a distinct group, which segregated a long time ago from other strains in the Indian Peninsula. Strong coevolutionary relationships with natural hosts are often observed among the hantaviruses [41,42]. However, the identification of $M$. booduga as a host for a THAIV-like virus suggests that a host-switching event occurred long ago, resulting in the coevolution of the Lanka virus with the Sri Lankan M. booduga lineage. The detection of high viral RNA copy numbers in genome-positive rodent tissues suggests a high possibility of shedding viruses in their excreta. Yasuda et al. reported that the Seoul orthohantavirus was excreted in feces when showing more than $10^{5}$ genome copies $/ \mathrm{mg}$ of lung tissues of $R$. norvegicus [43]. The Lanka virus and SA108 may pose elevated risks of human infections.

The two hantaviruses described herein were detected in CKDu endemic areas of Sri Lanka. It is of utmost importance to understand the epidemiological relationship between the virus infection and the prevailing human CKDu in the region. It is evident that young adult males engaged in farming activities year-round are significantly affected by CKDu in Sri Lanka. Male farmers working in agricultural fields are exposed to many external risk factors. We hypothesize that these individuals are exposed to hantaviruses in their working environments rather than in their homes. However, the infective virus and its source should be confirmed to determine possible interventions. Our study identified two candidate viruses and their distinct rodent hosts, which may transmit these viruses to humans in different habitats. Rattus species are well-adapted to peri-domestic environments and are thus distributed in both urban and rural areas. Their habitats are generally within houses or nearby neighborhoods, where they primarily feed on harvested crops stored inside homes or garbage dumps. On the other hand, M. booduga, commonly known as the little Indian field mouse, is most commonly found in agricultural fields, shrublands, and forest areas [39]. Therefore, the habitat of M. booduga, rather than that of R. rattus, is consistent with our hypothesized site of the acquiring a virus infection by humans. The geographic distribution of $M$. booduga includes India, where some regions are affected by CKDu. Hence, it is important to study whether Indian M. booduga strains can also carry hantaviruses that may confer a risk of CKDu.

$\mathrm{CKDu}$ has emerged as a significant public health problem in countries other than Sri Lanka, such as Nicaragua, El Salvador, and Costa Rica in Central America; some parts of India; and Egypt. Although the etiology has yet to be confirmed, extensive research has suggested some risk factors, such as heat/dehydration, infection/inflammation, and pesticides in Central American countries and water contamination/metals, pesticides, and infections in South Asian countries [44]. However, the hantavirus infection has, thus far, only been identified as a possible risk factor in CKDu patients from Sri Lanka [24,45,46].

Previous sero-epidemiological evidence indicated that THAIV-like hantaviruses infect both humans and rodents in CKDu hotspot regions. However, the unavailability of genetic information on hantaviruses circulating in the country has hindered the understanding of the relationship between these viruses and CKDu in Sri Lanka. Therefore, the current study aimed to fill the knowledge gap by identifying hantavirus genomes from rodent populations from a CKDu endemic region in Sri Lanka and further added a novel species to the list of hantavirus rodent hosts. 
In conclusion, the current study revealed the genomic basis of hantaviruses in Sri Lanka. Our findings provided new insights for further investigations based on specific diagnostics for detecting the hantavirus species circulating among rodents and humans in other areas of Sri Lanka. These findings may contribute to better characterizing the exposure in CKDu patients to understanding the involvement of hantavirus infections in the context of pathophysiology of CKDu in Sri Lanka.

Supplementary Materials: The following are available online at https: / www.mdpi.com/article / 10.3390/v13101984/s1: Figure S1: Phylogenetic tree based on cytb sequences of Mus booduga samples obtained in this study (in boldface) and other Mus spp. retrieved from databases. Figure S2: Phylogenetic tree based on M segment ORF sequences representing Muridae-borne hantaviruses and newfound viruses (in boldface) from this study. Figure S3: Phylogenetic tree based on L segment ORF sequences representing Muridae-borne hantaviruses and newfound viruses (in boldface) from this study. Table S1: List of primers used to amplify and sequence the S segment of the Lanka virus and SA108. Table S2: List of primers used to amplify and sequence the M segment of the Lanka virus and SA108. Table S3: List of primers used to amplify and sequence the L segment of the Lanka virus, SA108, and Thailand virus strain Thai-749. Table S4: Details of the accession numbers of $c y t b$ sequences and hantavirus genome sequences obtained from Mus booduga and Rattus rattus in this study. Table S5: Nucleotide and amino acid sequence identities of the $S$ segment ORF and nucleocapsid protein of the novel viruses with representative Muridae-borne hantaviruses. Table S6: Nucleotide and amino acid sequence identities of the M segment ORF and glycoprotein precursor of the novel viruses with representative Muridae-borne hantaviruses. Table S7: Nucleotide and amino acid sequence identities of the L segment ORF and L protein of the novel viruses with representative Muridae-borne hantaviruses.

Author Contributions: Conceptualization, H.E., C.D.G., and K.Y.; Data curation, D.S.M. and K.Y.; Funding acquisition, N.K., T.K., H.E., C.D.G., and K.Y.; Investigation, D.S.M., K.S., S.M.W.L., Z.W., G.R.A.F., P.S., N.K., T.K., and C.W.; Methodology, K.S., K.M., and Y.T.; Project administration, K.Y.; Resources, J.A.; Supervision, A.K.; Writing—original draft, D.S.M.; and Writing—review and editing, Y.D.S., C.D.G., and K.Y. All authors have read and agreed to the published version of the manuscript.

Funding: This research was funded by The Japanese Society for the Promotion of Science (JSPS) KAKENHI (19K10595, 16H06429, 16K21723, and 16H06431); U.S.-Japan Cooperative Medical Sciences Program Collaborative Awards, 2018 (AMED 18950142 and CRDF-Global 64067); Science and Technology Research Partnership for Sustainable Development (SATREPS 19jm0110019h0002); and Heiwa Nakajima Foundation. The National Science Foundation of Sri Lanka grant (RPHS/2016/CKDu/06) was received by Rohana Chandrajith (Study 03 PI-Chandika D. Gamage), Department of Geology, Faculty of Science, University of Peradeniya, Sri Lanka.

Institutional Review Board Statement: This study was conducted according to the guidelines of the Declaration of Helsinki and approved by the Ethics Committee of the Faculty of Veterinary Medicine and Animal Sciences of the University of Peradeniya, Sri Lanka (VER-16-007, approved on 20 December 2016).

Informed Consent Statement: Not applicable.

Data Availability Statement: Accession numbers of $c y t b$ sequences of hantavirus genome positive Mus booduga and Rattus rattus animals: LC556235 - LC556246, hantavirus genome sequences obtained from Mus booduga and Rattus rattus animals: LC553716 - LC553733, Thailand orthohantavirus strain Thai-749 L segment sequence: LC553715.

Acknowledgments: We thank Aiko Ohnuma from the International Institute for Zoonosis Control, Hokkaido University, for the technical support. We also thank the American journal experts for proofreading the final draft for any grammatical errors.

Conflicts of Interest: The authors declare no conflict of interest. The funders had no role in the design of the study; in the collection, analyses, or interpretation of the data; in the writing of the manuscript; or in the decision to publish the results. 


\section{References}

1. Chandrajith, R.; Nanayakkara, S.; Itai, K.; Aturaliya, T.N.; Dissanayake, C.B.; Abeysekera, T.; Harada, K.; Watanabe, T.; Koizumi, A. Chronic kidney diseases of uncertain etiology (CKDue) in Sri Lanka: Geographic distribution and environmental implications. Environ. Geochem. Health 2011, 33, 267-278. [CrossRef] [PubMed]

2. Athuraliya, N.T.; Abeysekera, T.D.; Amerasinghe, P.H.; Kumarasiri, R.; Bandara, P.; Karunaratne, U.; Milton, A.H.; Jones, A.L Uncertain etiologies of proteinuric-chronic kidney disease in rural Sri Lanka. Kidney Int. 2011, 80, 1212-1221. [CrossRef] [PubMed]

3. Jayasekara, K.B.; Dissanayake, D.M.; Sivakanesan, R.; Ranasinghe, A.; Karunarathna, R.H.; Priyantha Kumara, G.W. Epidemiology of chronic kidney disease, with special emphasis on chronic kidney disease of uncertain etiology, in the north central region of Sri Lanka. J. Epidemiol. 2015, 25, 275-280. [CrossRef] [PubMed]

4. Alwis, A.A.P.; Panawala, P.V.S. A review of the national response to CKDu in Sri Lanka. Sri Lanka J. Soc. Sci. 2019, 42, 83-100. [CrossRef]

5. Elliot, R.M. Molecular biology of the Bunyaviridae. J. Gen. Virol. 1990, 71, 501-522. [CrossRef] [PubMed]

6. Avsic-Zupanc, T.; Saksida, A.; Korva, M. Hantavirus infections. Clin. Microbiol. Infect. 2019, 21, e6-e16. [CrossRef]

7. Liu, R.; Ma, H.; Shu, J.; Zhang, Q.; Han, M.; Liu, Z.; Jin, X.; Zhang, F.; Wu, X. Vaccines and Therapeutics Against Hantaviruses. Front. Microbiol. 2019, 10, 2989. [CrossRef] [PubMed]

8. Kariwa, H.; Yoshimatsu, K.; Arikawa, J. Hantavirus infection in East Asia. Comp. Immunol. Microbiol. Infect. Dis. 2007, 30, 341-356. [CrossRef] [PubMed]

9. Elwell, M.R.; Ward, G.S.; Tingpalapong, M.; LeDuc, J.W. Serologic evidence of Hantaan-like virus in rodents and man in Thailand. Southeast. Asian J. Trop. Med. Public Health 1985, 16, 349-354. [PubMed]

10. Reynes, J.M.; Razafindralambo, N.K.; Lacoste, V.; Olive, M.M.; Barivelo, T.A.; Soarimalala, V.; Heraud, J.M.; Lavergne, A. Anjozorobe hantavirus, a new genetic variant of Thailand virus detected in rodents from Madagascar. Vector Borne Zoonotic. Dis. 2014, 14, 212-219. [CrossRef] [PubMed]

11. Plyusnina, A.; Ibrahim, I.N.; Plyusnin, A. A newly recognized hantavirus in the Asian house rat (Rattus tanezumi) in Indonesia. J. Gen. Virol. 2009, 90 Pt 1, 205-209. [CrossRef] [PubMed]

12. Johansson, P.; Yap, G.; Low, H.T.; Siew, C.C.; Kek, R.; Ng, L.C.; Bucht, G. Molecular characterization of two hantavirus strains from different rattus species in Singapore. Virol. J. 2010, 7, 15. [CrossRef]

13. Filippone, C.; Castel, G.; Murri, S.; Beaulieux, F.; Ermonval, M.; Jallet, C.; Wise, E.L.; Ellis, R.J.; Marston, D.A.; McElhinney, L.M.; et al. Discovery of hantavirus circulating among Rattus rattus in French Mayotte island, Indian Ocean. J. Gen. Virol. 2016, 97, 1060-1065. [CrossRef] [PubMed]

14. Pattamadilok, S.; Lee, B.H.; Kumperasart, S.; Yoshimatsu, K.; Okumura, M.; Nakamura, I.; Araki, K.; Khoprasert, Y.; Dangsupa, P.; Panlar, P.; et al. Geographical distribution of hantaviruses in Thailand and potential human health significance of Thailand virus. Am. J. Trop. Med. Hyg. 2006, 75, 994-1002. [CrossRef]

15. Chandy, S.; Okumura, M.; Yoshimatsu, K.; Ulrich, R.G.; John, G.T.; Abraham, P.; Arikawa, J.; Sridharan, G. Hantavirus species in India: A retrospective study. Indian J. Med. Microbiol. 2009, 27, 348-350. [CrossRef]

16. Gamage, C.D.; Yasuda, S.P.; Nishio, S.; Kularatne, S.A.; Weerakoon, K.; Rajapakse, J.; Nwafor-Okoli, C.; Lee, R.B.; Obayashi, Y.; Yoshimatsu, K.; et al. Serological evidence of Thailand virus-related hantavirus infection among suspected leptospirosis patients in Kandy, Sri Lanka. Jpn. J. Infect. Dis. 2011, 64, 72-75. [PubMed]

17. Rabemananjara, H.A.; Raharinosy, V.; Razafimahefa, R.M.; Ravalohery, J.P.; Rafisandratantsoa, J.T.; Andriamandimby, S.F.; Rajerison, M.; Rahelinirina, S.; Harimanana, A.; Irinantenaina, J.; et al. Human Exposure to Hantaviruses Associated with Rodents of the Murinae Subfamily, Madagascar. Emerg. Infect. Dis. 2020, 26, 587-590. [CrossRef]

18. Vitarana, T.; Colombage, G.; Bandaranayake, V.; Lee, H.W. Hantavirus disease in Sri Lanka [letter]. Lancet 1988, $2,1263$.

19. Dahanayaka, N.J.; Agampodi, S.B.; Bandaranayaka, A.K.; Priyankara, S.; Vinetz, J.M. Hantavirus infection mimicking leptospirosis: How long are we going to rely on clinical suspicion? J. Infect. Dev. Ctries 2014, 8, 1072-1075. [CrossRef]

20. Sunil-Chandra, N.P.; Clement, J.; Maes, P.; de Silva, H.J.; van Esbroeck, M.; van Ranst, M. Concomitant leptospirosis-hantavirus co-infection in acute patients hospitalized in Sri Lanka: Implications for a potentially worldwide underestimated problem. Epidemiol. Infect. 2015, 143, 2081-2093. [CrossRef]

21. Gamage, C.D.; Yoshimatsu, K.; Sarathkumara, Y.D.; Thiviyaaluxmi, K.; Nanayakkara, N.; Arikawa, J. Serological evidence of hantavirus infection in Girandurukotte, an area endemic for chronic kidney disease of unknown aetiology (CKDu) in Sri Lanka. Int. J. Infect. Dis. 2017, 57, 77-78. [CrossRef] [PubMed]

22. Yoshimatsu, K.; Gamage, C.D.; Sarathkumara, Y.D.; Kulendiran, T.; Muthusinghe, D.S.; Nanayakkara, N.; Gunarathne, L.; Shimizu, K.; Tsuda, Y.; Arikawa, J. Thailand orthohantavirus infection in patients with chronic kidney disease of unknown aetiology in Sri Lanka. Arch. Virol. 2019, 164, 267-271. [CrossRef]

23. Wijkstrom, J.; Jayasumana, C.; Dassanayake, R.; Priyawardane, N.; Godakanda, N.; Siribaddana, S.; Ring, A.; Hultenby, K.; Soderberg, M.; Elinder, C.G.; et al. Morphological and clinical findings in Sri Lankan patients with chronic kidney disease of unknown cause (CKDu): Similarities and differences with Mesoamerican Nephropathy. PLoS ONE 2018, 13, e0193056. [CrossRef] [PubMed]

24. Sarathkumara, Y.D.; Gamage, C.D.; Lokupathirage, S.; Muthusinghe, D.S.; Nanayakkara, N.; Gunarathne, L.; Shimizu, K.; Tsuda, Y.; Arikawa, J.; Yoshimatsu, K. Exposure to Hantavirus is a Risk Factor Associated with Kidney Diseases in Sri Lanka: A Cross Sectional Study. Viruses 2019, 11, 700. [CrossRef] [PubMed] 
25. Lokupathirage, S.M.W.; Muthusinghe, D.S.; Shimizu, K.; Nishigami, K.; Noda, K.; Tsuda, Y.; Sarathkumara, Y.D.; Gunawardana, S.; Arikawa, J.; Gamage, C.D.; et al. Serological Evidence of Thailand Orthohantavirus or Antigenically Related Virus Infection Among Rodents in a Chronic Kidney Disease of Unknown Etiology Endemic Area, Girandurukotte, Sri Lanka. Vector Borne Zoonotic Dis. 2019, 19, 859-866. [CrossRef] [PubMed]

26. Gamage, C.D.; Sarathkumara, Y.D. Chronic kidney disease of uncertain etiology in Sri Lanka: Are leptospirosis and Hantaviral infection likely causes? Med. Hypotheses 2016, 91, 16-19. [CrossRef] [PubMed]

27. Yasuda, S.P.; Vogel, P.; Tsuchiya, K.; Han, S.H.; Lin, L.K.; Suzuki, H. Phylogeographic patterning of mtDNA in the widely distributed harvest mouse (Micromys minutus) suggests dramatic cycles of range contraction and expansion during the mid- to late Pleistocene. Can. J. Zool 2005, 83, 1411-1420. [CrossRef]

28. Yasuda, S.P.; Gamage, C.D.; Koizumi, N.; Nishio, S.; Isozumi, R.; Shimizu, K.; Koma, T.; Amada, T.; Suzuki, H.; Yoshimatsu, K.; et al. Distinct genetic characteristics of Sri Lankan Rattus and Bandicota (Murinae, Rodentia) inferred from mitochondrial and nuclear markers. Genes Genet. Syst. 2014, 89, 71-80. [CrossRef]

29. Yoshimatsu, K.; Arikawa, J.; Kariwa, H. Application of a recombinant baculovirus expressing hantavirus nucleocapsid protein as a diagnostic antigen in IFA test: Cross reactivities among 3 serotypes of hantavirus which causes hemorrhagic fever with renal syndrome (HFRS). J. Vet. Med. Sci. 1993, 55, 1047-1050. [CrossRef]

30. Klempa, B.; Fichet-Calvet, E.; Lecompte, E.; Auste, B.; Aniskin, V.; Meisel, H.; Denys, C.; Koivogui, L.; ter Meulen, J.; Kruger, D.H. Hantavirus in African wood mouse, Guinea. Emerg. Infect. Dis. 2006, 12, 838-840. [CrossRef]

31. Ito, N.; Kakemizu, M.; Ito, K.A.; Yamamoto, A.; Yoshida, Y.; Sugiyama, M.; Minamoto, N. A comparison of complete genome sequences of the attenuated RC-HL strain of rabies virus used for production of animal vaccine in Japan, and the parental Nishigahara strain. Microbiol. Immunol. 2001, 45, 51-58. [CrossRef]

32. Huelsenbeck, J.P.; Ronquist, F. MRBAYES: Bayesian inference of phylogenetic trees. Bioinformatics 2001, 17, 754-755. [CrossRef]

33. Huson, D.H.; Scornavacca, C. Dendroscope 3: An interactive tool for rooted phylogenetic trees and networks. Syst. Biol. 2012, 61, 1061-1067. [CrossRef]

34. Laenen, L.; Vergote, V.; Calisher, C.H.; Klempa, B.; Klingstrom, J.; Kuhn, J.H.; Maes, P. Hantaviridae: Current Classification and Future Perspectives. Viruses 2019, 11, 788. [CrossRef]

35. Baek, L.J.; Yanagihara, R.; Gibbs, C.J.; Miyazaki, M.; Gajdusek, D.C. Leakey virus: A new hantavirus isolated from Mus musculus in the United States. J. Gen. Virol. 1988, 69 Pt 12, 3129-3132. [CrossRef]

36. Arthur, R.R.; Lofts, R.S.; Gomez, J.; Glass, G.E.; Leduc, J.W.; Childs, J.E. Grouping of hantaviruses by small (S) genome segment polymerase chain reaction and amplification of viral RNA from wild-caught rats. Am. J. Trop. Med. Hyg. 1992, 47, 210-224. [CrossRef] [PubMed]

37. Childs, J.E.; Ksiazek, T.G.; Spiropoulou, C.F.; Krebs, J.W.; Morzunov, S.; Maupin, G.O.; Gage, K.L.; Rollin, P.E.; Sarisky, J.; Enscore, R.E.; et al. Serologic and genetic identification of Peromyscus maniculatus as the primary rodent reservoir for a new hantavirus in the southwestern United States. J. Infect. Dis. 1994, 169, 1271-1280. [CrossRef]

38. Weidmann, M.; Schmidt, P.; Vackova, M.; Krivanec, K.; Munclinger, P.; Hufert, F.T. Identification of genetic evidence for dobrava virus spillover in rodents by nested reverse transcription (RT)-PCR and TaqMan RT-PCR. J. Clin. Microbiol. 2005, 43, 808-812. [CrossRef] [PubMed]

39. Jiang, J.F.; Zuo, S.Q.; Zhang, W.Y.; Wu, X.M.; Tang, F.; De Vlas, S.J.; Zhao, W.J.; Zhang, P.H.; Dun, Z.; Wang, R.M.; et al. Prevalence and genetic diversities of hantaviruses in rodents in Beijing, China. Am. J. Trop. Med. Hyg. 2008, 78, 98-105. [CrossRef] [PubMed]

40. Aplin, K.; Molur, S.; Nameer, P.O. Mus booduga (errata version published in 2017). IUCN Red List Threat. Species 2016. [CrossRef]

41. Plyusnin, A.; Vapalahti, O.; Lundkvist, A. Hantaviruses: Genome structure, expression and evolution. J. Gen. Virol. 1996, 77, 2677-2687. [CrossRef] [PubMed]

42. Schmaljohn, C.; Hjelle, B. Hantaviruses-A Global Disease Problem. Emerg. Infect. Dis. 1997, 3, 95-104. [CrossRef] [PubMed]

43. Yasuda, S.P.; Shimizu, K.; Koma, T.; Hoa, N.T.; Le, M.Q.; Wei, Z.; Muthusinghe, D.S.; Lokupathirage, S.M.W.; Hasebe, F.; Yamashiro, T.; et al. Immunological Responses to Seoul Orthohantavirus in Experimentally and Naturally Infected Brown Rats (Rattus norvegicus). Viruses 2021, 13, 665. [CrossRef] [PubMed]

44. Correa-Rotter, R.; Wesseling, C.; Johnson, R.J. CKD of unknown origin in Central America: The case for a Mesoamerican nephropathy. Am. J. Kidney Dis. 2014, 63, 506-520. [CrossRef]

45. Sunil-Chandra, N.P.; Jayaweera, J.; Kumbukgolla, W.; Jayasundara, M. Association of Hantavirus Infections and Leptospirosis With the Occurrence of Chronic Kidney Disease of Uncertain Etiology in the North Central Province of Sri Lanka: A Prospective Study With Patients and Healthy Persons. Front. Cell Infect. Microbiol. 2020, 10, 556737. [CrossRef] [PubMed]

46. Yih, W.K.; Kulldorff, M.; Friedman, D.J.; Leibler, J.H.; Amador, J.J.; Lopez-Pilarte, D.; Galloway, R.L.; Ramirez-Rubio, O.; Riefkohl, A.; Brooks, D.R. Investigating Possible Infectious Causes of Chronic Kidney Disease of Unknown Etiology in a Nicaraguan Mining Community. Am. J. Trop. Med. Hyg. 2019, 101, 676-683. [CrossRef] [PubMed] 